\title{
A post-Jaramillo age for the artefact-bearing layer TD4 (Gran Dolina, Atapuerca): New paleomagnetic evidence
}

\author{
Claudia Álvarez-Posada ${ }^{\mathrm{a}, *}$, Josep María Parés ${ }^{\mathrm{a}}$, Gloria Cuenca-Bescós ${ }^{\mathrm{b}}$, Jan Van der Made ${ }^{\mathrm{c}}$, \\ Jordi Rosell $^{\mathrm{d}}$, José María Bermúdez de Castro ${ }^{\mathrm{e}}$, Eudald Carbonell ${ }^{\mathrm{d}, \mathrm{f}}$ \\ ${ }^{a}$ Geochronology Program, CENIEH, Paseo Sierra de Atapuerca 3, 09002 Burgos, Spain \\ b Aragosaurus-IUCA, Departamento de Ciencias de la Tierra, Facultad de Ciencias, Universidad de Zaragoza, c/ Pedro Cerbuna, 12, 50009 Zaragoza, Spain \\ ${ }^{\mathrm{c}}$ Departamento de Paleobiología, Museo Nacional de Ciencias Naturales, C.S.I.C., c/ José G. Abascal 2, 28006 Madrid, Spain \\ d Institut Catalá de Paleoecologia Humana i Evolució Social, IPHES, Campus Sescelades (URV), 43007 Tarragona, Spain \\ e Paleobiology Program, CENIEH, Paseo Sierra de Atapuerca 3, 09002 Burgos, Spain \\ ${ }^{\mathrm{f}}$ Universitat Rovira i Virgili, Carrer de l'Escorxador, s/n, 43003 Tarragona, Spain
}

\section{A B S T R A C T}

The cave - site of Gran Dolina in Atapuerca preserves one of the most abundant records of Early to Middle Pleistocene sediments known so far. Therefore, establishing the chronology for the stratigraphic levels within the cavity is crucial. Since the early 1990s, subsequent excavations have allowed better access to the older stratigraphic levels TD4, TD5 and TD6 allowing for re-sampling with the aim of providing detailed chronology and testing whether the lithic industries-bearing layer TD4 has a post or pre-Jaramillo age, and hence establishing a better geochronological context for the lithic tools. In this study, we obtained negative magnetic polarity directions for these stratigraphic levels, a result consistent with previous studies that already identified the Matuyama-Brunhes boundary between TD7 and TD8 levels. In addition, several new ESR analysis, recently published, were carried out throughout the sequence, provide an age between 0.77 and 0.85 Ma for the upper limit of TD6 and an age of $0.91 \pm 0.25$ Ma for the lower limit of TD4. The age provided by ESR for TD6 is consistent with recent luminescence analysis, which provides a mean age of $846 \pm 57 \mathrm{ka}$. The combination of ESR, luminescence, biostratigraphy, with our new paleomagnetic results, supports a post-Jaramillo age for layer TD4 in Gran Dolina.

\section{Introduction}

The Atapuerca karst system contains one of the largest and most continuous records of Early and Middle Pleistocene age known so far. The cave sediments found in this karst system have been studied since the late 1980s (e.g., Aguirre et al., 1990; Carbonell et al., 1995; Parés and Pérez-González, 1995; Arsuaga et al., 1997; Bermúdez de Castro, 1997) contributing to a much better understanding of human evolution and dispersal outside the African continent.

Within this karstic complex, the Gran Dolina (TD) site has provided abundant archaeological and paleontological remains that document human activity and its relationship to the environment over the last one million years (Carbonell et al., 1995, 2008; Bermúdez-de Castro et al., 2008; Rodríguez et al., 2011; Rodríguez-Gómez et al., 2013). Different stratigraphic layers have been extensively studied and dated using numerous chronological methods such as biostratigraphy, luminescence, electron spin resonance (ESR) and paleomagnetism (Parés and
Pérez-González, 1995, 1999; Cuenca-Bescós et al., 1999, 2015; Falguères et al., 1999; García and Arsuaga, 1999; Berger et al., 2008; Parés et al., 2013; Arnold et al., 2015). Successive excavation seasons have expanded access to the sediments that fill the cave of Gran Dolina, making it possible to sample horizons that were not available before. This is particularly significant for magnetic reversal stratigraphy. The aim of this study is to build upon the existing magnetostratigraphy of levels TD6, TD5 and TD-4, which are currently much better and continuous exposed than when the original paleomagnetic study was done at this site, and to provide more information which complement the work reported by Parés et al. (2013).

Specifically, stratigraphic layer TD4 is a key unit, as its upper part contains remains of a lithic industry that confirms human presence in levels well below the Aurora stratum, now TD6-2 (Carbonell et al., 1995), which in turn predates the Matuyama-Brunhes boundary (here after MBB) (Parés and Pérez-González, 1995). The most recent absolute age available for this important layer is due to ESR, which gives an age

\footnotetext{
* Corresponding author.

E-mail address: cap0035@alu.ubu.es (C. Álvarez-Posada).
} 


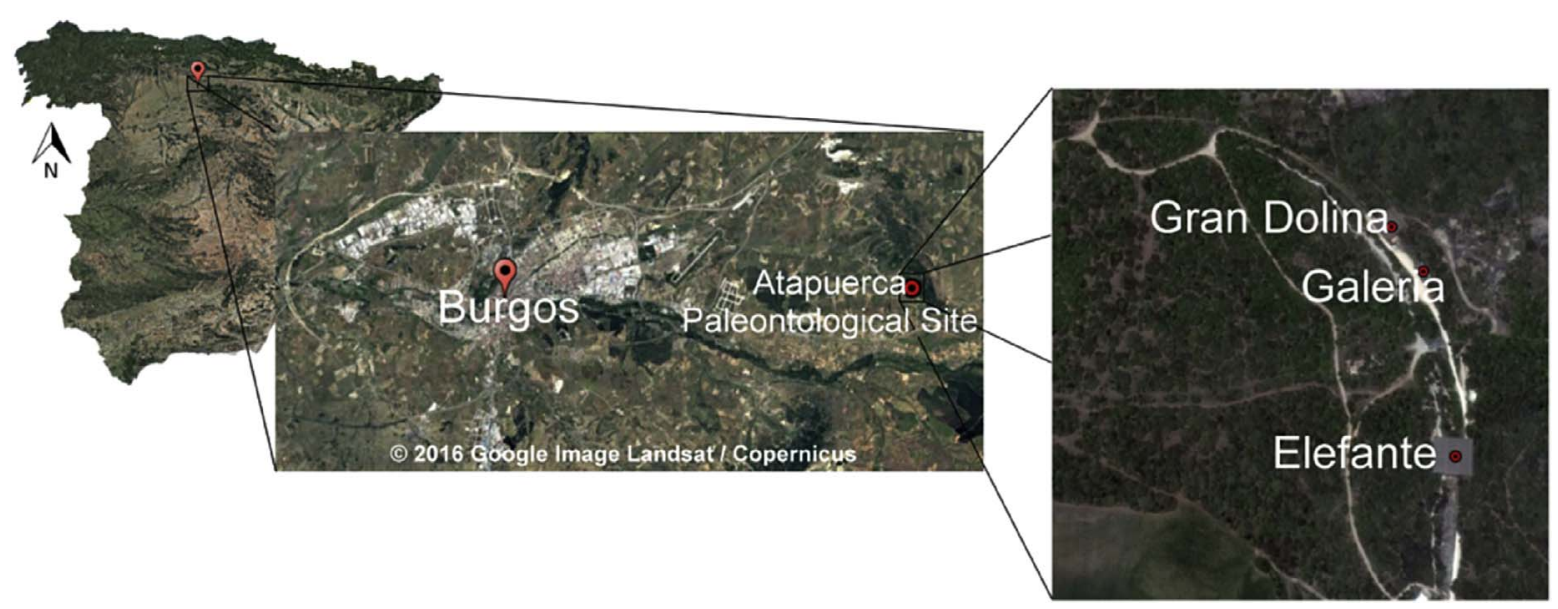

Fig. 1. Location of the Atapuerca karst system site. Images obtained from Google Earth free program (version 7.1.8.3036. Map data ${ }^{\circledR}$ 2016 Google, Digital Globe).

$902 \pm 149$ ka (Moreno et al., 2015) which could be compatible with the presence of the Jaramillo subchron (1001-1.069 ka) within the error margin. Therefore, the main goal of this study is to test whether the Jaramillo subchron is present in the section, thus establishing a better chronological framework for the levels TD4 to TD6 that allow a more accurate temporal range for the lithic industry and fossils found at TD4.

\subsection{Geological and stratigraphical context}

Sierra de Atapuerca is located about $16 \mathrm{~km}$ west of the city of Burgos (Fig. 1) within what is known as the "Bureba Corridor," a passage or connection between two of the largest Cenozoic basins of the Iberian Peninsula, the Duero and Ebro basins (Alonso-Gavilán et al., 2004). The mountain range corresponds to an anticline that structurally is part of the north western most sector of the Iberian chain and has been dissected in the Quaternary by the Arlanzón River (Benito-Calvo, 2004; Benito-Calvo et al., 2008). The mountain range consists mostly of Mesozoic limestones and dolomites, leading to a karst system which includes $4.7 \mathrm{~km}$ of explored passages, where numerous archaeological and paleontological remains have been found (Ortega et al., 2013).

\subsubsection{Gran Dolina (TD)}

This site consists a sedimentary filling, about $20 \mathrm{~m}$ thick, divided into 11 individual units labelled TD11 to TD1 from top to bottom (Gil et al., 1987) The stratigraphic nomenclature is still used with some modifications, specifically in the lower part, which includes names such as TDW4b, TD3-TD4 or TD3-4 (Cuenca-Bescós et al., 2001; PérezGonzález et al., 2001). A summary of the different nomenclatures can be found in Rodríguez et al. (2011). For the present manuscript, we will use the name of TD4 for this stratigraphic unit present in the lower part.

The sedimentary layers of the TD cavity, now exposed in a continuous vertical outcrop, include both interior facies sediments with little external influence (also known as autochthonous deposits in the literature), and entrance facies sediments, which originate outside the cave or at its entrance and which are deposited by different transport mechanisms mostly forming slope and talus cones. Level TD1 corresponds to a slackwater deposits capped by a speleothem at the base of TD4, and does not contain fossil. Levels TD4 to TD11 overlie the previous units and are formed mainly of pebbles, cobbles and sandy clay, corresponding to talus, slope wash and sliding bed mode deposits, and they contain numerous fossil remains.

A description of the levels addressed in this paper follows below:

- TD4: About $2 \mathrm{~m}$ thick dominated by breccia, with a reddish-brown sandy clay matrix and limestone pebbles between 10 and $15 \mathrm{~cm}$.

- TD5: About $2.5 \mathrm{~m}$ thick, consisting of a clast-supported breccia with pebbles and cobbles, up to $60 \mathrm{~cm}$ of diameter at the bottom, with a mud and sandy matrix and a dark brown clay level at the top.

- TD6: $2-2.5 \mathrm{~m}$ thick with abundant clasts ranging from breccia to gravels with a very hard and less abundant clay matrix.

A more comprehensive and detailed description of the sedimentary infill of Gran Dolina can be found in Campaña et al. (2015, 2016).

\subsection{Biostratigraphical context of TD4, TD5 and TD6}

The mammal assemblages from the TD4, TD5 and TD6 are Biharian in the European biostratigraphy. The preceding Villafranchian Mammal Age is a biochronological unit based on large mammals covering the time interval from the Late Pliocene through most of the Early Pleistocene in Southern Europe. It roughly spans from around 3.5 Ma to about 1.0 Ma (Rook and Martínez-Navarro, 2010) and are found in preJaramillo or Jaramillo layers from several localities in Europe (see Cuenca-Bescós et al., 2015 for a comprehensive review). In Spain, the end of the Villafranchian is characterized by the faunal unit defined in Sima del Elefante as the Atapuerca FU 1 (Cuenca-Bescós and García, 2007). This FU1 records the oldest occurrence of fossil remains of Homo in Europe (Carbonell et al., 2008) together with at rodent association dominated by the Allophaiomys species Allophaiomys lavocati (Laplana and Cuenca-Bescós, 2000), from the Lower Red Units of Sima del Elefante (knows as TELRU levels, López-García et al., 2011), in Atapuerca. This faunal association is unique and is situated in the layers prior to the Jaramillo event in the localities were this event is recorded such as the layer 10 of the site of Vallparadís, EVT 10 (Estació de Vallparadís 10), see Minwer-Barakat et al. (2011) and Duval et al. (2011). The micro fauna from TD4, TD5, TD6 and lower part of TD7, below the MMB and hence Early Pleistocene, is dominated by the Mimomys savini which disappears short after the MBB event in Gran Dolina TD8 (level TD8b, Table 1), and from the faunal units FU2 to FU4 (Cuenca-Bescós et al., 2015, 2010).

Relevant large mammal species from TD4 include Bison voigtstedtensis, which is assumed to be a descendant of Bison menneri (Made et al., 2015), a species of Eucladoceros replacing the closely related Eucladoceros giulii, Megaceroides solilhacus, which is a descendant of Eucladoceros pliotarandoides and Crocuta, which first appeared in Atapuerca (García and Arsuaga, 2001; Made et al., 2015). The first appearance of Cervus elaphus in Europe seems to have been diachronic, appearing before the Jaramillo in Montenegro, within the Jaramillo in Germany, and in TD4 in Spain (Made and Dimitrijevic, 2015). These taxa suggest a post, rather than a pre-Jaramillo age for TD4. A summary of the different stratigraphic ranges of taxa which appears (first or last) in the latest Matuyama until Jaramillo subchron is shown in Fig. 2. Further information about those taxa can be found in the 
Table 1

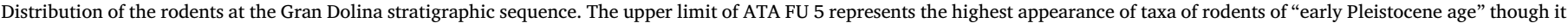
appears above the Matuyama-Brunhes boundary, the proposed limit between the Early-Middle Pleistocene.

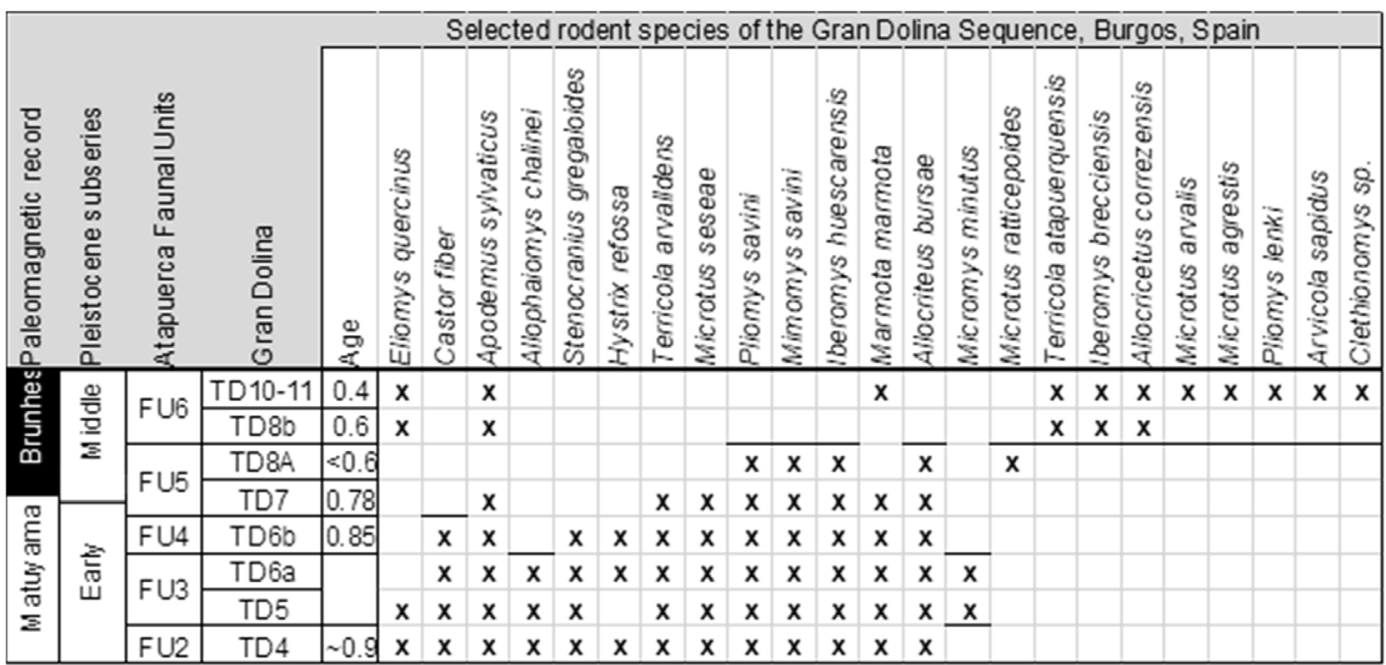

supplementary data (Appendix A, Tables S1 and S2, and the bibliographical references there contained).

\section{Material and methods}

Owning to the cohesiveness and hardness of the materials of the studied levels, two different procedures were used to obtain the samples for this study. The top of level TD6 is cohesive and indurated, and an electric radial saw was used in order to obtain hand blocks between 8 and $4 \mathrm{~cm}$, which were processed to obtain individual samples about $8 \mathrm{~cm}^{3}$ into the laboratory. For levels TD5 and TD4, with more abundant and softer clay matrix a ceramic knife has been used to cut individual samples of sediment in situ. In both cases, samples were oriented in situ with a standard compass and clinometer. Whenever possible, we have tried to obtain consecutive samples in all stratigraphic levels, although given the accessibility to the outcrop (currently a vertical wall) and the abundance of paleontological remains, this has not always been possible. In total, we have sampled 86 sites spread across the three levels studied, obtaining 140 individual specimens of $8 \mathrm{~cm}^{3}$.

The paleomagnetic analyses were performed at the Paleomagnetism Laboratory of the National Research Center for Human Evolution (CENIEH, Burgos) and consisted in measuring the natural remanent

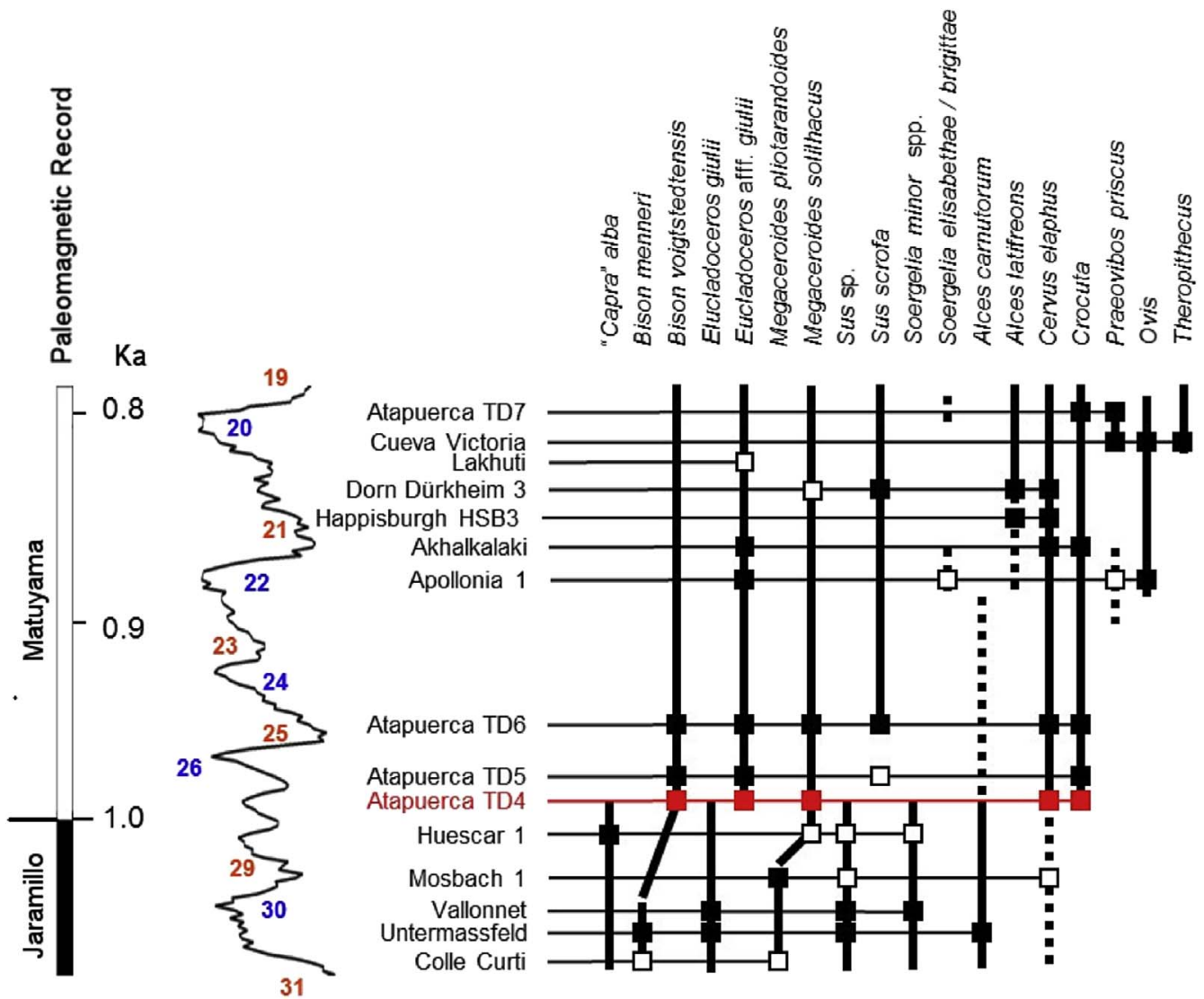

Fig. 2. Stratigraphic ranges of taxa with last appearances in the Jaramillo or first or last appearances in the latest Matuyama and the localities in which they Occur. Modified from Van der Made et al. (2015). 
magnetization (NRM) of the samples and their progressive demagnetization. We used a Superconducting Rock Magnetometer model 755-4K (2G Enterprises) with a built in 3-axis degausser system for alternating field demagnetization (AF) up to $170 \mathrm{mT}$, and an oven model TD-48SC (ASC Scientific) for thermal demagnetization (TH). Also, an Impulse Magnetizer, model IM-10-30 ASC has been used to obtain isothermal remanent magnetization (IRM) acquisition curves.

Of the 140 individual specimens obtained, 118 have been analysed, of which $73(62 \%)$ have been thermally demagnetized, with an initial increase of $50{ }^{\circ} \mathrm{C}$ to reach $350{ }^{\circ} \mathrm{C}$, and then reduce the step at $30{ }^{\circ} \mathrm{C}$, reaching $650{ }^{\circ} \mathrm{C}$. 24 specimens (20\%) have been demagnetized using AF, reaching up $0.1 \mathrm{~T}$. Nine specimens $(8 \%)$ have been demagnetized first at $130{ }^{\circ} \mathrm{C}$ and then with AF until a peak field of $50 \mathrm{mT}$. Twelve specimens $(10 \%)$ has been used to obtain the IRM curves, and their progressive thermal demagnetization. The information about the in-dividual samples analysed and the statistical results are provided in the supplementary data (Appendix A Table S3).

After visual inspection of the obtained Zijderveld (1967) diagrams, we have determined, based in the most stable component of the NRM (Natural Remanent Magnetization), the primary component, known as Characteristic Remanent Magnetization (ChRM) direction, which we favour to be the original primary magnetization acquired at the of deposition, for each sample. Afterwards we obtained the fisherian mean of the ChRM directions (appling various programs, such as Pmag, Tauxe, 1988; VPD7, Ramón \& Pueyo, 2014), and last, we calculated the Virtual Geomagnetic Pole (VGP) latitude for each site based on the mean ChRM direction.

\section{Results}

Paleomagnetic results show a moderate NRM intensity, with values ranging between $6.79 \times 10^{3} \mathrm{~A} / \mathrm{m}$ to $3.35 \times 10^{-4} \mathrm{~A} / \mathrm{m}$, well above the noise level of the magnetometer that we used. The IRM acquisition curves present a low coercivity phase, with a saturation below $100 \mathrm{mT}$, indicating that the main carrier of magnetization is magnetite (Fig. 3).

After visual inspection of the Zijderveld diagrams, samples have been categorized by a statistical distribution of the MAD (maximum angular deviation) by calculated the mean of all data. The value obtained was a numerical mean of 7.05 , which we use as a reference to classify the data as: type I $(25 \%)$ include specimens in which the MAD value is equal or less at 7.05; type II (24\%) specimens have a MAD value over 7.05; and type III (52\%) for those specimens which show an erratic or noisy behaviour, and there is no possibility to obtain data (Fig. 4). In thermally demagnetized samples having type I and II, we have identified, in almost all of them, the presence of two components: a low temperature, between $20^{\circ} \mathrm{C}$ to $350{ }^{\circ} \mathrm{C}$, and high temperature (where ChRM has been determined) which reaches $530^{\circ} \mathrm{C}$. Above this temperature, behaviour typically becomes erratic (Fig. 4). Both observations, mid-unblocking temperature and the saturation curves of the IRM

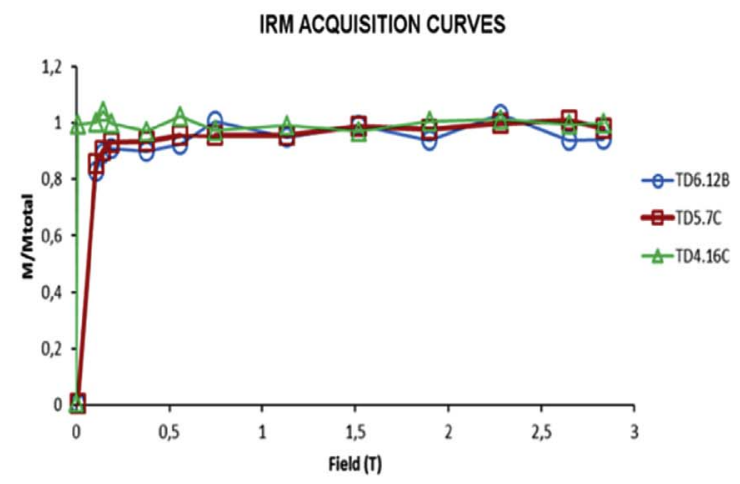

experiments at low fields, confirm magnetite as the major ferromagnetic mineral present in the sediments. This result is coherent with a number of existing paleomagnetic and rock magnetic analysis (Bógalo et al., 2003; Parés et al., 2013).

The orientation of the low temperature component is NW and positive, not distinguishable from the present Earth's magnetic field at the locality, while the high temperature component has a SE and upwards direction. The low stability component (NW positive) has been interpreted as a recent overprinting, and the latter is considered as the primary magnetization (Fig. 5).

The reversal stratigraphy is based on the VGP Latitude position and sites have been classed based on the $k$ precision parameter: class 1 if $k \geq 10$; class 2 if $k<10$, and class 3 if only one sample was used (Table 2). The VGP Latitude plot values shows a dominance of negative polarities (Fig. 6), ranging from -78 to -33 .

The obtained reverse magnetozone encompasses stratigraphic levels TD6, TD5 and TD4, and is interpreted as the Matuyama chron, as a major change in polarity, from reverse to normal observed near the limit between units TD7 and TD8 was assigned to the MatuyamaBrunhes Boundary (Parés and Pérez-González, 1995, 1999) and later corroborated by OSL and ESR dating (e.g., Arnold et al., 2015; Falguères et al., 1999; Moreno et al., 2015). The obtained reverse magnetozone is only interrupted by three non-consecutive sites that show positive magnetization directions which cannot be unambiguously interpreted as geomagnetic short events. These few horizons displaying normal polarity could simply correspond to remagnetized sediments or else due to as an insufficient removal of the present day field overprint and therefore are not included in the discussion and interpretation of the results.

Recent ESR analyses carried out by Moreno et al. (2015) in the lower section of Gran Dolina, and specifically from the mid - lower section of TD4, give an age of $902 \pm 149 \mathrm{ka}$; whereas the upper part of TD6, includes an OSL (Optical Stimulated Luminiscence) chronology by Arnold et al. (2015) which results in a mean age of $846 \pm 57$ ka for TD6 level, clearly below the - Matuyama-Brunhes limit (Fig. 6). Our new magnetostratigraphic results can then be combined with such absolute ages to interpret the magnetic polarity.

\section{Discussion and conclusions}

The magnetostratigraphy obtained in this study reveals essentially reverse polarity from TD4 to TD6 levels that agrees with the presence of the MBB at the upper part of level TD7 (Parés and Pérez-González, 1999, 1995). ESR analyses carried out in Aurora stratum (upper part of TD6), just below TD7, show an age between 0.77 and 0.85 Ma for such level (Duval et al., 2012; Falguères et al., 2013, 1999), and is consistent with the average age of $846 \pm 57$ ka for TD6 provided by luminescence (Arnold et al., 2015). Also, the ESR analyses (Moreno et al., 2015) on quartz grains in the lower section of Gran Dolina, provide an average

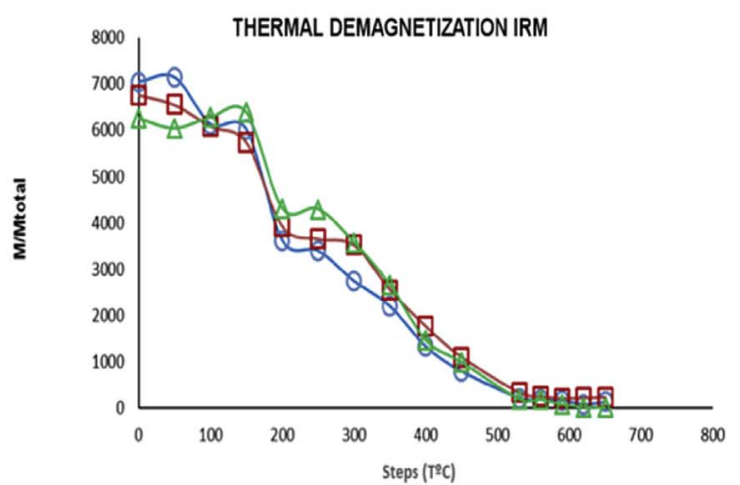

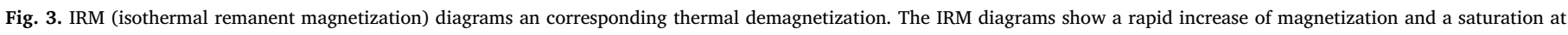
about $0.1-0.2 \mathrm{mT}$. Maximum unblocking temperatures are between 550 and $600{ }^{\circ} \mathrm{C}$. 

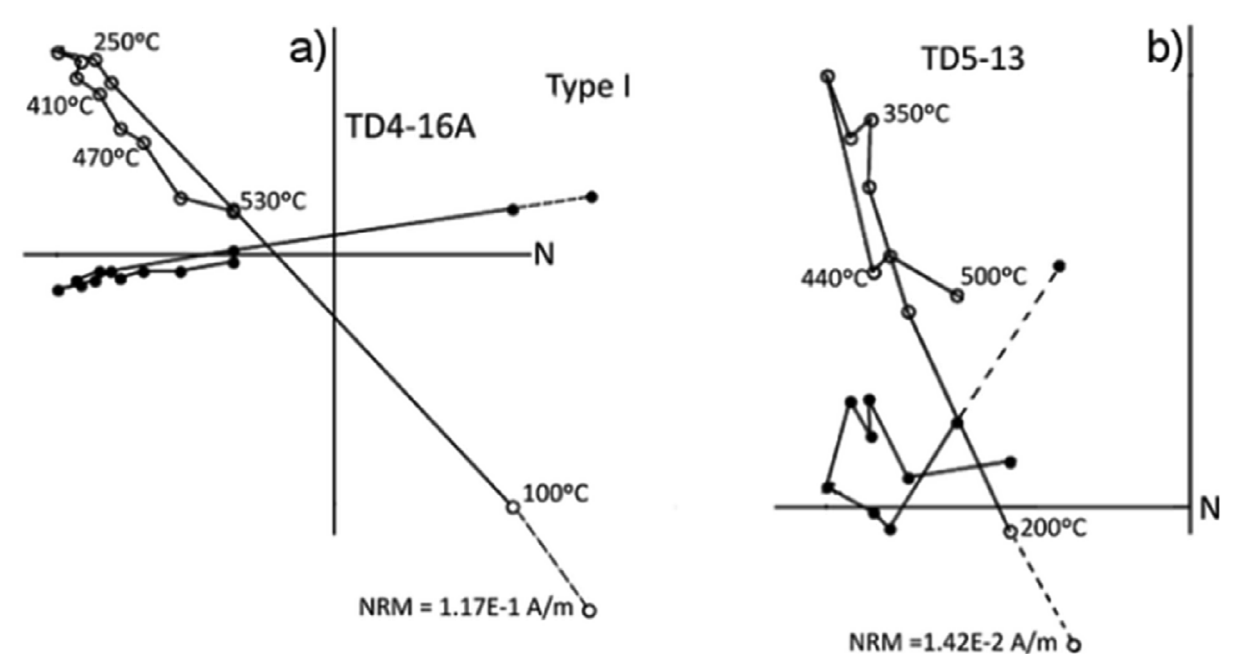

Fig. 4. Orthogonal Zijderveld diagrams representing the three types of behaviour obtained in this study. Open (closed) circles show vertical (horizontal) components of magnetization. Type I, diagrams a) and b); Type II, c) and d); and Type III e) and f).

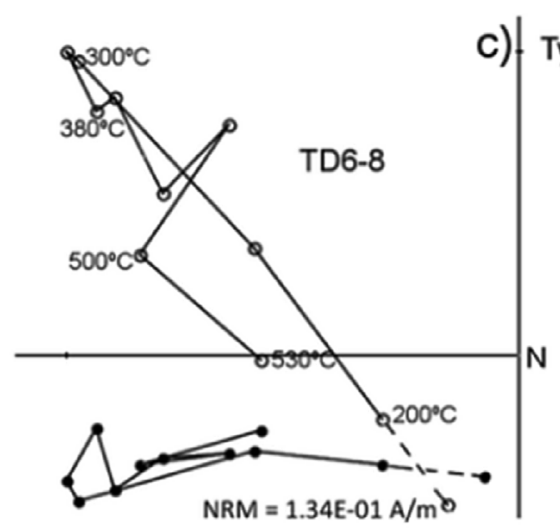

Type II

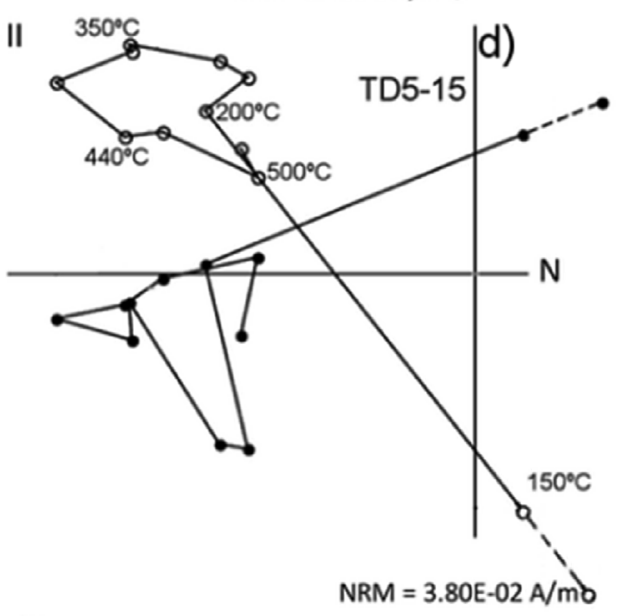

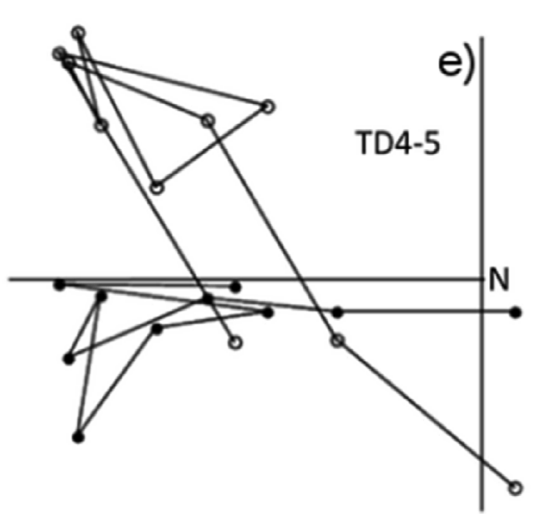

Type III

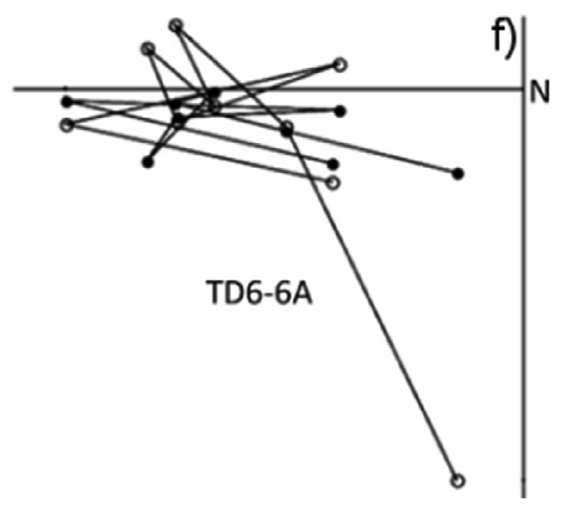

age for TD4 level of $0.91 \pm 0.25 \mathrm{Ma}$. Hence the window of time comprised in levels TD6 to TD4 levels is constrained between 0.85 and $0.91 \mathrm{Ma}$. The lower limit of such a window of time, due the uncertainty of the ESR age $(\sim 10 \%)$, is a priori compatible with the presence of the Jaramillo subchron (1.00-1.07 Ma) in the lower part of the section, a possibility that our new results allow to re-evaluate. The presence of exclusively reverse polarity from TD4 to TD7, together with the ESR age, strongly suggests that such stratigraphic interval was formed after the Jaramillo subchron, so sometime after $1.00 \mathrm{Ma}$. The Jaramillo subchron has a duration of about 60-70 ka and hence, given that no hiatuses or major erosional surfaces are observed in this part of the stratigraphy (e.g., Campaña et al., 2015), it is unlikely that the Jaramillo Subchron was simply not recorded in the stratigraphic record.

The insectivores (Eulipothyphla) and arvicolines (Rodentia) of levels TD4, TD5, TD6 and lower part of TD7 are characteristic of the end of the Early Pleistocene. These are the late Biharian microfaunas, which are partially correlated with the first two thirds of the Galerian large mammal faunas in the continental European biostratigraphy (CuencaBescós et al., 2010, 2015). These observations are compatible with a post-Jaramillo age for TD4.

Overall, when comparing the magnetostratigraphy obtained in this work with the Quaternary geomagnetic instability time scale (Singer, 2014) (Fig. 7), we can conclude that lithic tool-bearing layer TD4 of Gran Dolina has an early Pleistocene age, and on the basis of all existing data, that the studied section post-dates the Jaramillo Subchron $(<1.0$ Ma). Our conclusion is consistent with recent results from Italy (e.g., Muttoni et al., 2010, 2009) in that a significant pulse in human dispersal in southern Europe took place between the Jaramillo subchron and the Brunhes - Matuyama boundary (0.99-0.78 Ma) Whether the lithic tools found in TD4 (Carbonell and Rodríguez, 1994; Carbonell 


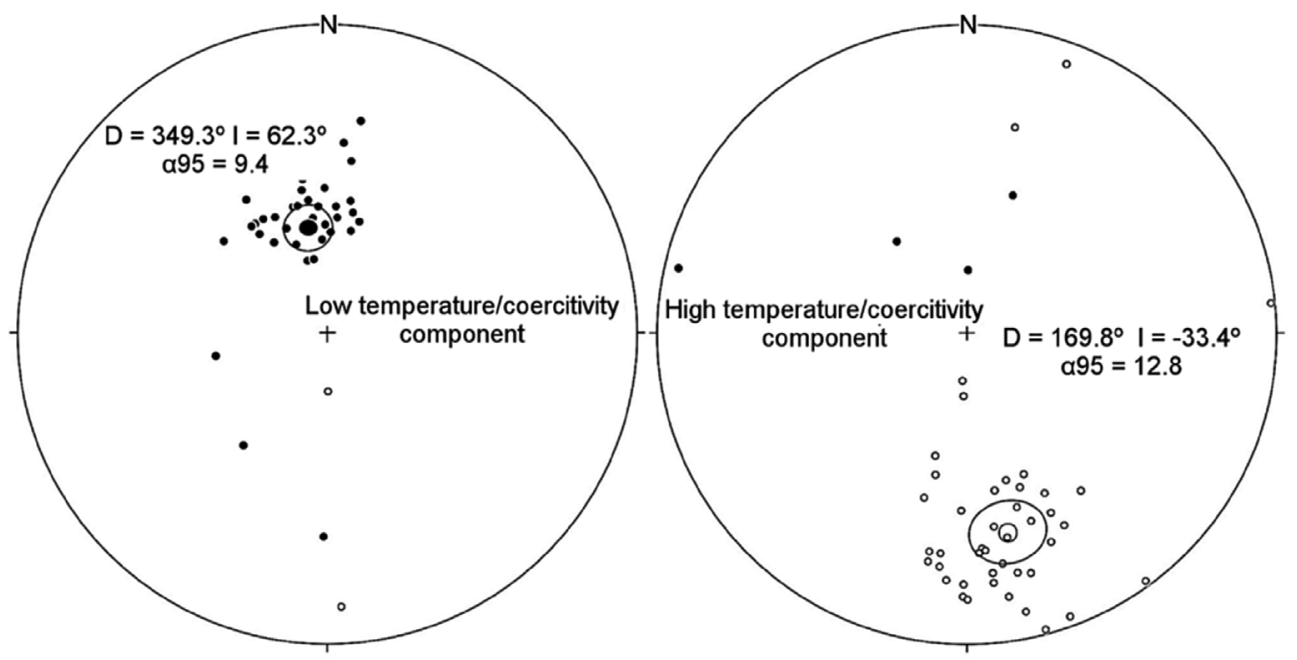

Fig. 5. Equal area, lower hemisphere projection of high and low temperature magnetization components. Each point represents a magnetization component of one individual sample. White and black dots represent vectors onto the upper and lower hemisphere respectively. Alfa-95 circles around the mean directions are also shown. The direction of the low stability components is consistent with the present Earth's field, and is considered to be recent overprint Also the expected GAD inclination is about $61.3^{\circ}$, which is within the error of the mean of the lower temperature component.

Table 2

The samples are grouped in sites and ordered by depth, showing the VGP Latitude calculated for each site. Depth = Stratigraphic depth of the sequence beginning from the top of Gran Dolina; Site = sampling site; $\mathbf{N}=$ Number of individual specimens used; VGPLat $^{\mathbf{o}}=$ latitude of the Virtual Geomagnetic Pole; Class $(\mathbf{K})=$ precision parameter; sites are classified according to the value of $\mathrm{k}$ : class 1 if $\mathrm{k}>10$, class 2 if $\mathrm{k}<10$, and class 3 if one specimen was used.

\begin{tabular}{|c|c|c|c|c|}
\hline Depth & Site & $\mathrm{N}$ & VGP Lat & Class (K) \\
\hline 7,06 & TD6.1 & 2 & -53 & 1 \\
\hline 7,18 & TD6.9 & 1 & -58 & 3 \\
\hline 7,2 & TD6.10 & 1 & -59 & 3 \\
\hline 7,23 & TD6.8 & 1 & -56 & 3 \\
\hline 7,27 & TD6.12 & 1 & -65 & 3 \\
\hline 7,4 & TD6.15 & 1 & -53 & 3 \\
\hline 7,44 & TD6.14 & 1 & -57 & 3 \\
\hline 7,53 & TD6.13 & 1 & -65 & 3 \\
\hline 7,55 & TD6.7 & 2 & -61 & 1 \\
\hline 7,8 & TD6.17 & 1 & -59 & 3 \\
\hline 8 & TD6.20 & 2 & -62 & 1 \\
\hline 8,05 & TD6.22 & 1 & -69 & 3 \\
\hline 8,09 & TD6.23 & 2 & -78 & 1 \\
\hline 8,26 & TD6.21 & 1 & -63 & 3 \\
\hline 8,52 & TD6.24 & 1 & -61 & 3 \\
\hline 8,95 & TD5.2C & 1 & -33 & 3 \\
\hline 9,1 & TD5.15 & 1 & -56 & 3 \\
\hline 9,18 & TD5.13 & 1 & -56 & 6 \\
\hline 9,21 & TD5.14 & 1 & 48 & 3 \\
\hline 9,24 & TD5.9 & 1 & -38 & 3 \\
\hline 9,31 & TD5.20 & 1 & 4 & 3 \\
\hline 9,36 & TD5.12 & 2 & -46 & 1 \\
\hline 9,66 & TD5.18 & 1 & -61 & 3 \\
\hline 9,68 & TD5.17 & 1 & -68 & 3 \\
\hline 10,11 & TD4.10 & 1 & -64 & 3 \\
\hline 10,17 & TD4.11 & 2 & -71 & 1 \\
\hline 10,21 & TD4.1 & 1 & 40 & 3 \\
\hline 10,4 & TD4.12 & 1 & 29 & 3 \\
\hline 10,4 & TD4.4 & 2 & -55 & 1 \\
\hline 10,57 & TD4-1.1 & 1 & -60 & 3 \\
\hline 11,39 & TD4.29 & 1 & 40 & 3 \\
\hline 11,66 & TD4.31 & 1 & 76 & 3 \\
\hline 12,05 & TD4.20 & 2 & -35 & 2 \\
\hline 12,12 & TD4.18 & 1 & -70 & 3 \\
\hline 12,22 & TD4.15 & 1 & -68 & 3 \\
\hline 12,24 & TD4.16 & 2 & -37 & 2 \\
\hline 12,26 & TD4.17 & 2 & -69 & 1 \\
\hline 12,29 & TD4.19 & 2 & -68 & 1 \\
\hline 12,34 & TD4.14 & 1 & -63 & 3 \\
\hline 12,41 & TD4.13 & 1 & 11 & 3 \\
\hline
\end{tabular}

et al., 2001), which include cores and flakes, were transported in to the cave by natural processes or else they are in situ needs further work. No cut-marks have been observed so far in the large mammal fossils found at the layer, which would suggest transport of the artifacts into the cave, although work in progress will shed more light into this important issue.

Although Gran Dolina TD6 layer holds an unprecedented, well dated record of hominin fossils ca $0.9 \mathrm{Ma}$, the underlying and hence older stratigraphic layer TD4, which also reveals human presence through lithic tools, confirms that occupation at the site of Gran Dolina was, if not rather continuous, at least highly constant through the Pleistocene.

From a geological point of view, stratigraphic layer TD4 reveals an important change in karst dynamics, as the sediment type, grain size, and texture indicate all together the development of a proximal cave entrance and a significant drop of the water table. Notably, the small mammals recorded in these layers are indicators of dry conditions in comparison with the small mammal assemblages of layers TD5 and TD6. Underlying older levels (TD1) display interior facies (fluvial, slackwater deposits) and proximity to the phreatic level (Parés et al., submt.), with no external connections and hence preventing the accumulation of large fossils or artifacts into the cave. Therefore, a major paleoenvironmental change occurred between the top of TD1 and TD4, which led to the development of a cave entrance in Gran Dolina (TD), allowing the beginning of the accumulation of exterior sediments. As a consequence, the fossiliferous record (external input) of the lower part of Gran Dolina might be biased by the geologic processes associated with such environmental change (transport and accumulation).

\section{Acknowledgments}

Access and permission to collect samples in Atapuerca was granted by Junta de Castilla y León. The authors are deeply indebted to the Atapuerca Research Team (EIA) and the Fundación Atapuerca for continuous backup of this research. In particular, to the team of scientists that excavate level TD4 for their cooperation and patience throughout the sampling process. Thank are also debt to the "river team" that wash-sieve the sediments obtained during the excavations. Financial support for this work was obtained from Junta de Castilla y León and from MINECO projects CGL2010-16821 (J.M. Parés) and CGL2015-65387-C3-1-P (J.M. Bermúdez de Castro), and CGL201238434-C03-01 (G. Cuenca-Bescós). C. Álvarez-Posada has been the beneficiary of a pre-doctoral MINECO FPI grant BES-2011-048877.

\section{Appendix A. Supplementary data}

Supplementary data related to this article can be found at http://dx. doi.org/10.1016/j.quageo.2018.01.003. 



\section{Legend}

\begin{tabular}{|c|c|}
\hline Mud flow & Clay \\
\hline
\end{tabular}

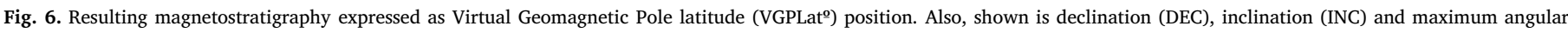

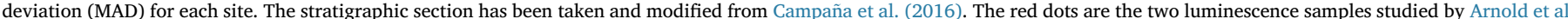

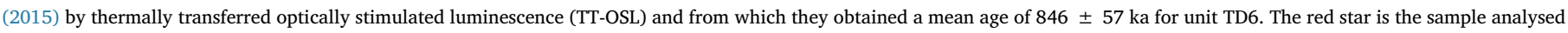
byMoreno et al. (2015) at the TD4 unit. (For interpretation of the references to colour in this figure legend, the reader is referred to the Web version of this article.)

Age (ka)

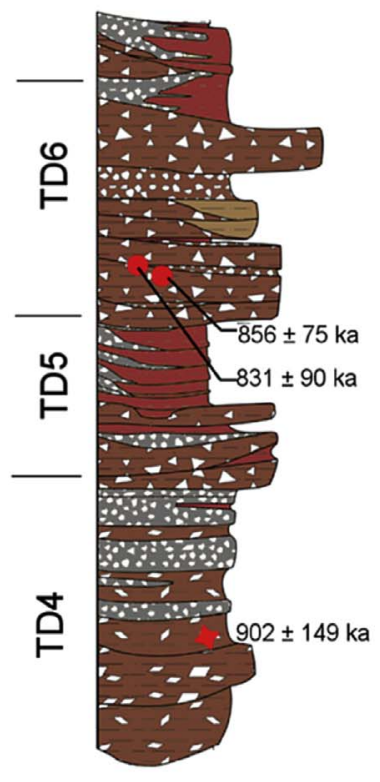

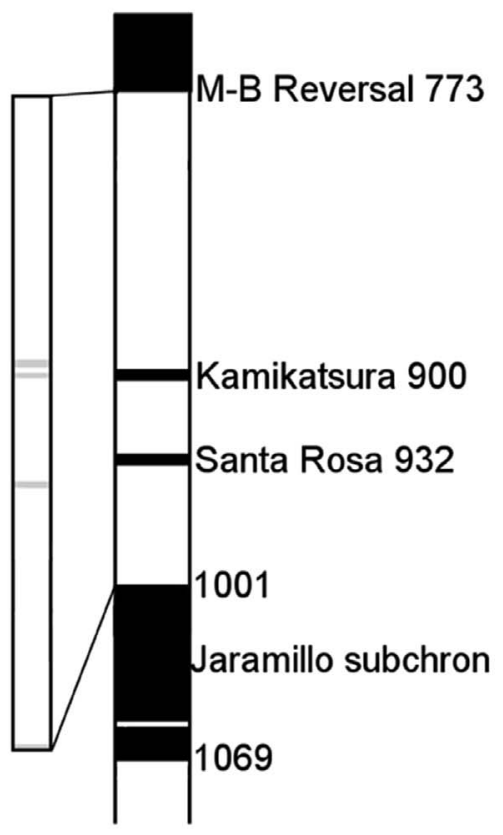

Legend
ESR Sample

TT - OSL Samples
Fig. 7. Comparison of the magnetostratigraphy obtained in this study with the GITS (geomagnetic instability time scale) of Matuyama Reverse Chron (modified from Singer, 2014). The stratigraphic section has been taken and modified from Campaña et al., (2016). Although we find values of normal polarity in depths of 9 , 10 and $12.5 \mathrm{~m}$ (the grey levels in the magnetostratigraphy) we cannot interpret them in terms of full reversals of the geomagnetic field (see text for discussion). 


\section{References}

Aguirre, E., Arsuaga, J.L., Bermúdez de Castro, J.M., Carbonell, E., Ceballos, M., Díez, C., Enamorado, J., Fernández-Jalvo, Y., Gil, E., Gracia, A., Martín-Nájera, A., Martínez, I., Morales, J., Ortega, A.I., Rosas, A., Sánchez, A., Sánchez, B., Sesé, C., Soto, E., Torres, T.J., 1990. The Atapuerca sites and the ibeas hominids. Hum. Evol. 5, 55-73. http://dx.doi.org/10.1007/BF02436474.

Alonso-Gavilán, G., Armenteros, I., Carballeira, J., Corrochano, A., Huerta, P., Rodríguez, J., 2004. Cuenca del Duero. In: Vera, J.A. (Ed.), Geología de España. SGE-IGME, Madrid, pp. 531-586.

Arnold, L.J., Demuro, M., Parés, J.M., Pérez-González, A., Arsuaga, J.L., Bermúdez de Castro, J.M., Carbonell, E., 2015. Evaluating the suitability of extended-range luminescence dating techniques over early and Middle Pleistocene timescales: published datasets and case studies from Atapuerca, Spain. Quat. Int. 389, 167-190. http://dx doi.org/10.1016/j.quaint.2014.08.010.

Arsuaga, J.L., Bermúdez de Castro, J.M., Carbonell, E., 1997. Preface for 'Special Issue: the Sima de los Huesos Hominid Site'. J. Hum. Evol. 33, 105-107.

Benito-Calvo, A., 2004. Análisisgeomorfológico y reconstrucción de paleopaisaje neógenos y cuaternarios en laSierra de Atapuerca y el valle medio del río Arlanzón. Universidad Complutensede Madrid, Servicio de Publicaciones, Madrid doi: ISBN 84669-2585.

Benito-Calvo, A., Pérez-González, A., Parés, J.M., 2008. Quantitative reconstruction of Late Cenozoic landscapes: a case study in the Sierra de Atapuerca ( Burgos, Spain ). Earth Surf. Process. Landforms 33, 196-208. http://dx.doi.org/10.1002/esp.

Berger, G.W., Pérez-González, A., Carbonell, E., Arsuaga, J.L., Bermúdez de Castro, J.M., $\mathrm{Ku}, \mathrm{T}$.-L.L., 2008. Luminescence chronology of cave sediments at the Atapuerca paleoanthropological site, Spain. J. Hum. Evol. 55, 300-311. http://dx.doi.org/10. 1016/j.jhevol.2008.02.012.

Bermúdez-de Castro, J., Perez-Gonzalez, A., Martinon-Torres, M., Gomez-Robles, A., Rosell, J., Prado, L., Sarmiento, S., Carbonell, E., 2008. A new early Pleistocene hominin mandibule from Atapuerca-TD6, Spain. J. Hum. Evol. 55, 729-735.

Bermúdez de Castro, J.M., 1997. A hominid from the lower Pleistocene of Atapuerca, Spain: possible ancestor to neandertals and modern humans. Science 276, 1392-1395. http://dx.doi.org/10.1126/science.276.5317.1392.

Bógalo, M.F., Heller, F., Villaláin, J.J., Calvo, M. Osete, M.L., Pérez-González, A., 2003. Propuesta metodológica para la caracterización de la mineralogía magnética en estudios paleoambientales. Aplicación al yacimiento de Atapuerca. Geogaceta 34, 107-110.

Campaña, I., Benito-Calvo, A., Pérez-González, A., Ortega, A.I., Bermúdez de Castro, J.M., Carbonell, E., 2015. Pleistocene sedimentary facies of the Gran Dolina archaeo-paleoanthropological site (Sierra de Atapuerca, Burgos, Spain). Quat. Int. 1-17. http:// dx.doi.org/10.1016/j.quaint.2015.04.023.

Campaña, I., Pérez-González, A., Benito-Calvo, A., Rosell, J., Blasco, R., Bermúdez De Castro, J.M., Carbonell, E., Arsuaga, J.L., 2016. New Interpretation of the Gran Dolina-TD6 Bearing Homo Antecessor Deposits through Sedimentological Analysis. Nature Publishing Group, pp. 1-13. http://dx.doi.org/10.1038/srep34799.

Carbonell, E., Bermúdez de Castro, J.M., Arsuaga, J.L., Díez, C., Rosas, A., Cuenca-Bescós, G., Sala, R., Mosquera, M., Rodríguez, X.P., 1995. Lower Pleistocene hominids and artefacts from Atapuerca - TD6 (Spain). Science 269, 826-829.

Carbonell, E., Bermúdez de Castro, J.M., Parés, J.M., Pérez-González, A., Cuenca-Bescós, G., Ollé, A., Mosquera, M., Huguet, R., Made, J. van der, Rosas, A., Sala, R., Vallverdú, J., García, N., Granger, D.E., Martinón-Torres, M., Rodríguez, X.P., Stock, G.M., Vergès, J.M., Allué, E., Burjachs, F., Cáceres, I., Canals, A., Benito, A., Díez, C., Lozano, M., Mateos, A., Navazo, M., Rodríguez, J., Rosell, J., Arsuaga, J.L., 2008. The first hominin of Europe. Nature 452, 465-469. http://dx.doi.org/10.1038/ nature 06815 .

Carbonell, E., Mosquera, M., Ollé, A., Rodríguez, X.P., Sahnouni, M., Sala, R., Vergès, J.M., Rodriguez, X.P., 2001. Structure morphotechnique de l'industrie lithique du Pléistocène inférieur et moyen d'Atapuerca (Burgos, Espagne). Anthropologie 105, 259-280. http://dx.doi.org/10.1016/S0003-5521(01)80016-9.

Carbonell, E., Rodríguez, X.P., 1994. Early Middle Pleistocene deposits and artefacts in the Gran Dolina site (TD4) of the 'Sierra de Atapuerca' (Burgos, Spain). J. Hum. Evol. 26, 291-311.

Cuenca-Bescós, G., Blain, H.A., Rofes, J., Lozano-Fernández, I., López-García, J.M., Duval, M., Galán, J., Núñez-Lahuerta, C., 2015. Comparing two different Early Pleistocene microfaunal sequences from the caves of Atapuerca, Sima del Elefante and Gran Dolina (Spain): biochronological implications and significance of the Jaramillo subchron. Quat. Int. 389, 148-158. http://dx.doi.org/10.1016/j.quaint.2014.12.059.

Cuenca-Bescós, G., Canudo, J.I., Laplana, C., 2001. La séquence des rongeurs (Mammalia) des sites du Pléistocène inférieur et moyen d' Atapuerca (Burgos, Espagne). Anthropologie 105, 115-130. http://dx.doi.org/10.1016/S0003-5521(01)80009-1.

Cuenca-Bescós, G., García, N., 2007. Biostratigraphic succession of the early and Middle Pleistocene mammals faunas of the Atapuerca caves sites (Burgos, Spain). Courier Forschungsinstitut Senckenberg Weimar 259, 99-101.

Cuenca-Bescós, G., Laplana, C., Canudo, J.I., 1999. Biochronological implications of the arvicolidae (Rodentia, Mammalia) from the lower Pleistocene hominid-bearing level of trinchera Dolina 6 (TD6, Atapuerca, Spain). J. Hum. Evol. 37, 353-373. http://dx doi.org/10.1006/jhev.1999.0306.

Cuenca-Bescós, G., Rofes, J., López-García, J.M., Blain, H.A., De Marfá, R.J., GalindoPellicena, M.A., Bennásar-Serra, M.L., Melero-Rubio, M., Arsuaga, J.L., Bermúdez de Castro, J.M., Carbonell, E., 2010. Biochronology of Spanish Quaternary small vertebrate faunas. Quat. Int. 212, 109-119. http://dx.doi.org/10.1016/j.quaint.2009. 06.007

Duval, M., Falguères, C., Bahain, J.J., Grün, R., Shao, Q., Aubert, M., Dolo, J.M., Agustí, J., Martínez-Navarro, B., Palmqvist, P., Toro-Moyano, I., 2012. On the limits of using combined U-series/ESR method to date fossil teeth from two Early Pleistocene archaeological sites of the Orce area (Guadix-Baza basin, Spain). Quat. Res. 77, 482-491. http://dx.doi.org/10.1016/j.yqres.2012.01.003.
Duval, M., Moreno, D., Shao, Q., Voinchet, P., Falguères, C., Bahain, J.J., Garcia, T., Garcia, J., Martinez, K., 2011. Datacion por ESR del yacimiento arqueologico del Pleistoceno inferior de Vallparadís (Terrassa, Cataluna, Espana). Trab. Prehist. 68, $7-24$.

Falguères, C., Bahain, J.-J.J., Yokoyama, Y., Arsuaga, J.L., Bermudez de Castro, J.M., Carbonell, E., Bischoff, J.L., Dolo, J.-M.M., 1999. Earliest humans in Europe: the age of TD6 gran Dolina, Atapuerca, Spain. J. Hum. Evol. 37, 343-352. http://dx.doi.org/ 10.1006/jhev.1999.0326.

Falguères, C., Bahain, J.J., Bischoff, J., Pérez-González, A., Ortega, A.I., Ollé, A., Quiles, A., Ghaleb, B., Moreno, D., 2013. Combined ESR/U-series chronology of Acheulian hominid bearing layers at Trinchera Galería site, Atapuerca, Spain. J. Hum. Evol. 65, $168-184$.

García, N., Arsuaga, J.L., 2001. Les carnivores (Mammalia) des sites dus Pléistocène ancien et moyen d'Atapuerca (Espagne). L'Anthropologie 105, 83-94.

García, N., Arsuaga, J.L., 1999. Carnivores from the Early Pleistocene hominid-bearing Trinchera Dolina 6 (Sierra de Atapuerca, Spain). J. Hum. Evol. 37, 415-430. http:// dx.doi.org/10.1006/jhev.1999.0325.

Gil, E., Aguirre, E., Hoyos, M., 1987. Contexto estratigráfico. In: Aguirre, E., Carbonell, E., Bermúdez de Castro, J.M. (Eds.), El Hombre Fósil de Ibeas Y El Pleistoceno de La Sierra de Atapuerca, pp. 47-54 Valladolid.

Laplana, C., Cuenca-Bescós, G., 2000. Una nueva especie de Microtus (Allophaiomys) (Arvicolidae, Rodentia, Mammalia) en el Pleistoceno inferior de la Sierra de Atapuerca (Burgos, España). Rev. Esp. Paleon 15, 77-88.

López-García, J.M., Blain, H.-A., De Marfá, R., García, A., Martinell, J., Bennàsar, M.L., Cuenca-Bescós, G., 2011. Small-mammals from the Middle Pleistocene layers of the Sima del Elefante (Sierra de Atapuerca, Burgos, northwestern Spain). Geol. Acta 9, $29-43$.

Made, J van der, Dimitrijevic, V., 2015. Eucladoceros montenegrensis n. sp. and other Cervidae from the lower Pleistocene of trlica (Montenegro). Quat. Int. 2 (389), 90-118.

Made, J van der, Rosell, J., Blasco, R., 2015. Faunas from Atapuerca at the Early-Middle Pleistocene limit: the ungulates from level TD8 in the context of climatic change. Quat. Int. 433, 1-51.

Minwer-Barakat, R., Madurell-Malapeira, J., Alba, D.M., Aurell-Garrido, J., De EstebanTrivigno, S., Moyà-Solà, S., 2011. Pleistocene rodents from the Torrent de Vallparadís section (Terrassa, northeastern Spain) and biochronological implications. J. Vertebr. Paleontol. 31, 849-865. http://dx.doi.org/10.1080/02724634.2011.576730.

Moreno, D., Falguères, C., Pérez-González, A., Voinchet, P., Ghaleb, B., Despriée, J. Bahain, J.J., Sala, R., Carbonell, E., Bermúdez de Castro, J.M., Arsuaga, J.L., 2015. New radiometric dates on the lowest stratigraphical section (TD1 to TD6) of Gran Dolina site (Atapuerca, Spain). Quat. Int. 30, 535-540. http://dx.doi.org/10.1016/j. quageo.2015.05.007.

Muttoni, G., Scardia, G., Kent, D.V., 2010. Human migration into Europe during the late early Pleistocene climate transition. Palaeogeogr. Palaeoclimatol. Palaeoecol. 296, 79-93. http://dx.doi.org/10.1016/j.palaeo.2010.06.016.

Muttoni, G., Scardia, G., Kent, D.V., Swisher, C.C., Manzi, G., 2009. Pleistocene magnetochronology of early hominin sites at Ceprano and Fontana Ranuccio, Italy. Earth Planet Sci. Lett. 286, 255-268. http://dx.doi.org/10.1016/j.epsl.2009.06.032.

Ortega, A.I., Benito-Calvo, A., Pérez-González, A., Martín-Merino, M.A., Pérez-Martínez, R., Parés, J.M., Aramburu, A., Arsuaga, J., Bermúdez de Castro, J.M., Carbonell, E., 2013. Evolution of multilevel caves in the Sierra de Atapuerca (Burgos, Spain) and its relation to human occupation. Geomorphology 196, 122-137. http://dx.doi.org/10. 1016/j.geomorph.2012.05.031.

Parés, J.M., Arnold, L., Duval, M., Demuro, M., Pérez-González, A., Bermúdez de Castro, J.M., Carbonell, E., Arsuaga, J.L., 2013. Reassessing the age of Atapuerca-TD6 (Spain): new paleomagnetic results. J. Archaeol. Sci. 40, 4586-4595. http://dx.doi. org/10.1016/j.jas.2013.06.013.

Parés, J.M., Pérez-González, A., 1995. Paleomagnetic age for hominid fossils at Atapuerca archaeological site, Spain. Science 269, 830-832. http://dx.doi.org/10.1126/science. 7638599.

Parés, J.M.M., Pérez-González, A., 1999. Magnetochronology and stratigraphy at gran Dolina section, Atapuerca (Burgos, Spain). J. Hum. Evol. 37, 325-342. http://dx.doi. org/10.1006/jhev.1999.0331.

Pérez-González, A., Parés, J.M., Carbonell, E., Aleixandre, T., Ortega, A.I., Benito, A., Martin Merino, M.Á., 2001. Géologie de la Sierra de Atapuerca et stratigraphie des remplissages karstiques de Galería et Dolina (Burgos, Espagne). L'Anthropologie 105, 27-43. http://dx.doi.org/10.1016/S0003-5521(01)80004-2.

Rodríguez-Gómez, G., Rodríguez, J., Martín-González, J.Á., Goikoetxea, I., Mateos, A., 2013. Modeling trophic resource availability for the first human settlers of Europe: the case of Atapuerca TD6. J. Hum. Evol. 64, 645-657. http://dx.doi.org/10.1016/j. jhevol.2013.02.007.

Rodríguez, J., Burjachs, F., Cuenca-Bescós, G., García, N., Van der Made, J., Pérez González, A., Blain, H.A., Expósito, I., López-García, J.M., García Antón, M., Allué, E., Cáceres, I., Huguet, R., Mosquera, M., Ollé, A., Rosell, J., Parés, J.M., Rodríguez, X.P., Díez, C., Rofes, J., Sala, R., Saladi, P., Vallverdú, J., Bennasar, M.L., Blasco, R. Bermúdez de Castro, J.M., Carbonell, E., 2011. One million years of cultural evolution in a stable environment at Atapuerca (Burgos, Spain). Quat. Sci. Rev. 30, 1396-1412. http://dx.doi.org/10.1016/j.quascirev.2010.02.021.

Rook, L., Martínez-Navarro, B., 2010. Villafranchian: the long story of a Plio-Pleistocene European large mammal biochronologic unit. Quat. Int. 219, 134-144. http://dx.doi. org/10.1016/j.quaint.2010.01.007.

Singer, B.S., 2014. A quaternary geomagnetic instability time scale. Quat. Geochronol. 21, 29-52. http://dx.doi.org/10.1016/j.quageo.2013.10.003.

Zijderveld, J.D.A., 1967. Ac demagnetization of rocks: analysis of results. In: Collinson, D.W., Creer, K.M., Runcorn, S.K. (Eds.), Methods in Palaeomagnetism. Elsevier, Amsterdam, New York, pp. 254-286. http://dx.doi.org/10.1016/j.neuroscience. 2010.03.066. 